\title{
Investigation of jatropha seed oil as austempering quenchant for ductile cast iron
}

\author{
Akor Terngu $^{1} *$, Gundu David Terfa ${ }^{2}$ \\ ${ }^{1}$ Department of Mechanical Engineering, Nigerian Defence Academey Kaduna \\ ${ }^{2}$ Department of Mechanical Engineering, University of Agriculture, Makurdi \\ *Corresponding authorE-mail: terngu.akor@gmail.com
}

Copyright $\odot 2014$ Akor Terngu, Gundu David Terfa. This is an open access article distributed under the Creative Commons Attribution License, which permits unrestricted use, distribution, and reproduction in any medium, provided the original work is properly cited.

\begin{abstract}
Austempering is a multi-step process that includes austenitizing, followed by cooling rapidly enough to avoid the formation of pearlite to a temperature above the martensite start (Ms) and then holding until the desired microstructure is formed. It is an isothermal heat treatment process that, when applied to cast iron, produces components that, in many cases, have properties superior to those process by conventional heat treatment. Salt bath has been recognized as the conventional quenching medium for austempering. This study investigates the suitability of jatropha seed oil as quenching medium for asaustempering ductile cast iron. Test samples were austenitized at 9500C; socked for 1hr; austempered for varying periods of 1, 2, 3, 4 and $5 \mathrm{hrs}$. The result showed significant increase in tensile strength and impact energy apart from achieving an appreciable increase in hardness. It also tally with recommended values of ductile cast iron austempered in salt bath, implying that jatropha oil can be used as hot bath for the austempering of ductile cast iron.
\end{abstract}

Keywords: Ausferrite, Austempering, Austenitized, Matrix So, Cked.

\section{Introduction}

Ductile cast iron frequently referred to as nodular or spheroid graphite iron is a recent member of the family of cast irons. It contains spheroid graphite in the as cast condition, through the addition of nucleating agents such as cerium or magnesium to the liquid iron, [1] The graphite spheroids are dispersed in a matrix similar to that of steel with the graphite spheroids exerting only a minor influence on the mechanical properties in contrast to the effect of graphite flakes in gray cast iron,[2]. The matrix structure then has the greatest effect on the properties of the iron. Ductile irons are therefore a family of alloys, which combine the advantages of gray cast iron (low melting point, good fluidity and castability, excellent machinability, and good wear resistance) with the engineering advantages of steel ( high strength, toughness, ductility, hot workability and hardenability),[3].

Austempering is a high performance isothermal heat treatment that imparts superior performance to ferrous metals. It is a multi-step process that includes austenitizing, followed by cooling rapidly enough to avoid the formation of pearlite to a temperature above the martensite start (Ms) and then holding until the desired microstructure is formed. The metallurgical phase obtained is called ausferrite. It is composed of acicular ferrite and residual austenite saturated by carbon atoms. The high silicon content of ductile iron suppresses the formation of carbides which are normally associated with bainitic reactions, allowing the rejected carbon to austenite surrounding the formed ferrite platelets during transformation, [4]. The carbon content in austenite is enriched and makes it thermally stable to retain even well below room temperature. During austempering ductile iron undergoes two-stage transformation process. In stage I, the austenite $(\Upsilon)$ decomposes into ferrite $(\alpha)$ and high carbon austenite $\left(\Upsilon_{\mathrm{HC}}\right)$ :

$\Upsilon \rightarrow \alpha+\Upsilon_{\mathrm{HC}}$

(stage I)

If the sample is held at the austempering temperature for too long, then a next reaction (stage II) takes place where high carbon austenite further decomposes into ferrite and carbide: 
$\Upsilon_{\mathrm{HC}} \rightarrow \alpha+$ carbide

(stage II)

The product of this second reaction is undesirable because it embrittles the material and degrades the mechanical properties. Therefore, this reaction should be avoided during heat-treatment. [3].

Austempered ductile iron has been long recognized for its high tensile strength, ductility, wear resistance and toughness making it a possible replacement for forged steels in many applications [5] and [6]. Strength to weight ratio is more than that of aluminium. ADI can replace aluminium also, where strength of the component is to be considered for minimum weight.

Salt bath has been the conventional quenching medium for austempering heat treatment of steels and cast iron. However, oils are among the quenching media of industrial significance. Oils of mineral and vegetable origins have been used as quenchant. The use of oils of mineral origin is however compromised by the film or nucleate boiling heat transfer they exhibit, resulting to lower-temperature cooling rates. This characteristic is absent in vegetable oils, where heat transfer is dominated by convective cooling, [7]. The cooling rate for vegetable oils is faster than that of comparable quenchants, making them suitable for austempering heat treatment. The cooling time-temperature and cooling-rate curves obtained show that the cooling properties of series of vegetable oils appear to be comparable to each other, [8].

The development of a quenchant from locally source raw materials is expected to be a significant contribution to the foundry industry. Jatropha seed oil is non-consumable vegetable oil which has little or no application in human nutrition This paper investigated the potential of jatropha seed oil as austempering quenchant for ductile cast iron.

\section{Materials}

The raw materials used in this study include jatropha seed oil and ductile cast iron. Jatropha seeds were harvested from Rafin Sewa Gora; Zango LGA of Kaduna State and processed for oil at National Research Institute for Chemical Technology, (NARICT), Zaria, Kaduna State; while ductile cast iron was produced in a commercial foundry (Nasir Foundries Jos Platu State).

\section{Methodology}

Fifteen "Y" blocks of dimensions $25 \times 25 \mathrm{~mm}$ by $300 \mathrm{~mm}$ height were produced using open ladle treatment method for this study. Sandwich treatment technique was used. In this technique, the ferrosilicon alloy was placed on a pocked in the bottom of an open heated ladle and covered with scrap. The melt was poured on the other side of the ladle to react with the magnesium alloy effectively. The melt was then cast into ' $\mathrm{Y}$ ' blocks. The pouring temperature was $1380{ }^{\circ} \mathrm{C}$.

The chemical composition (in wt. \%) of castings was as follows: $3.63 \mathrm{C}, 2.60 \mathrm{Si}, 0.35 \mathrm{Mn}, 0.02 \mathrm{~S}, 0.03 \mathrm{P}, 0.03 \mathrm{Mg}$, the balance was Fe. Samples for tensile tests and charpy impact tests were machined from the blocks. Screw-type samples (ASTM.A370-68) with $10 \mathrm{~mm}$ diameter and $75 \mathrm{~mm}$ gauge length were used for tensile tests. All tensile tests were performed at room temperature at a strain rate 1.3x10-3s-1. The dimensions of the notched charpy samples (ASTM E 23-93a) were 10x10x50mm. Impact tests were also performed at room temperature applying 300J impact energy. Prior to testing samples were austenitised at $950{ }^{\circ} \mathrm{C}$ for $1 \mathrm{~h}$ and then austempered in hot jatropha oil bath at $250{ }^{\circ} \mathrm{C}$ for varying periods of $1 \mathrm{hr}, 2 \mathrm{hrs}, 3 \mathrm{hrs}$, $4 \mathrm{hrs}$ and $5 \mathrm{hrs}$. After austempering samples were air cooled, after which they were washed with kerosene. Samples were tested in the as cast and austempered condition. A minimum of three samples were tested for each heat-treatment condition.

\section{Result and discussion}

The results obtained from this research work are displayed in form of graphs in Fig. 1 -3. Fig. 1 shows the effect of austempering time on the tensile and yield strength of ductile cast iron specimens austenised at $950{ }^{\circ} \mathrm{C}$ and austempered in hot jatropha, seed oil bath maintained at $250{ }^{\circ} \mathrm{C}$. The tensile strength reached a maximum at $4 \mathrm{hrs}$ then decreased. This increase in tensile strength is attributed to the formation of ausferrite in the matrix of the ductile cast iron. At the austempering period of $5 \mathrm{hrs}$ a drop in tensile strength was noticed, indicating that the reaction crossed from toughening stage to embrittlement. Stage I reaction $\Upsilon_{\mathrm{H}} \rightarrow \alpha+\Upsilon_{\mathrm{HC}}$ (toughening); Sage II reaction $\Upsilon_{\mathrm{HC}} \rightarrow \alpha+\varepsilon-$ carbides (embrittlement). [7]. There is a corresponding increase in the yield strength of the tested specimen as shown on Figure 1.

Figure 2, shows percentage elongation and reduction in area of the austempered ductile cast iron increasing with austempering time. This is also in agreement with the stage I austempering reaction shown above. Figure 3 shows the effect of austempering time on the hardness and impact strength of ductile cast iron specimen's austempered in jatropha, hot oil baths. It is evident that as the austempering time increased the hardness values of the austempered specimens decreased to minimum values of 286HB, 269HB, and 256HB. The drop in hardness at $2 \mathrm{hrs}, 3 \mathrm{hrs}, 4 \mathrm{hrs}$ and 5 hrs austempering periods shows transformation of the matrix to stabilized austenite and ferrite structure. The impact strength also increased progressively with austempering time. This indicates a progression in the stage 1 reaction, increasing the stability of austenite in the ferrite matrix of the cast iron. This is in agreement with [9]. The highest 
impact strength value of austempered ductile iron for this study was 69J in hot jatropha oil bath at 4hrs austempering period.

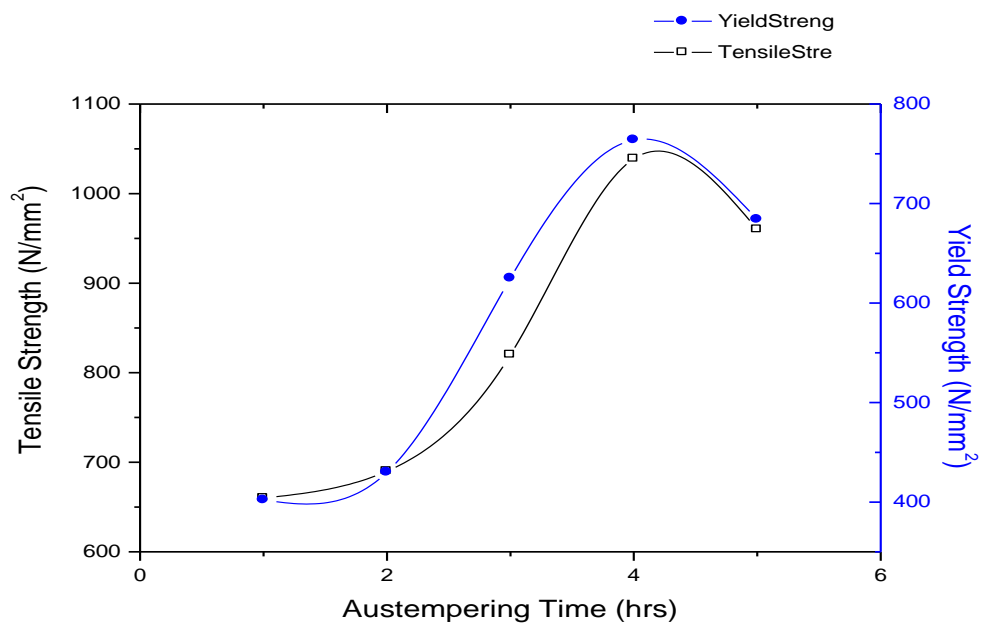

Fig. 1: Effect of Austempering Time on the Tensile and Yield Strength of Ductile Cast Iron Austenitized at $950^{\circ} \mathrm{C}$ and Austempered in Hot Jatropha Oil at $250^{\circ} \mathrm{C}$ for Varying Periods.

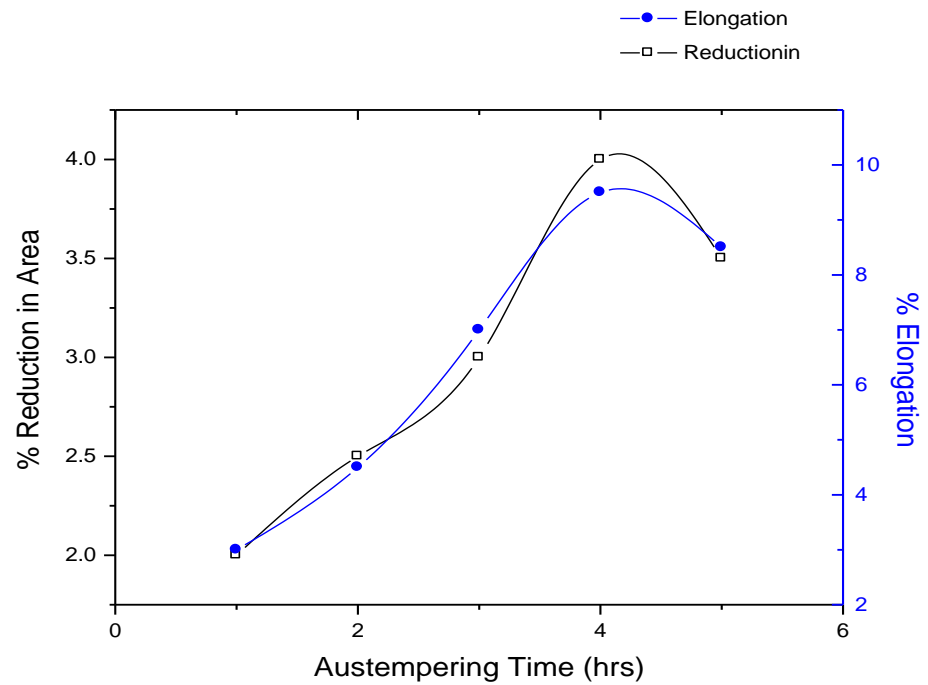

Fig. 2: Effect of Austempering Time on Elongation and Contraction of Ductile Cast Iron Austenitized at $950^{\circ} \mathrm{C}$ and Austempered in Hot Jatropha Oil at $250^{\circ} \mathrm{C}$ for Varying Periods.

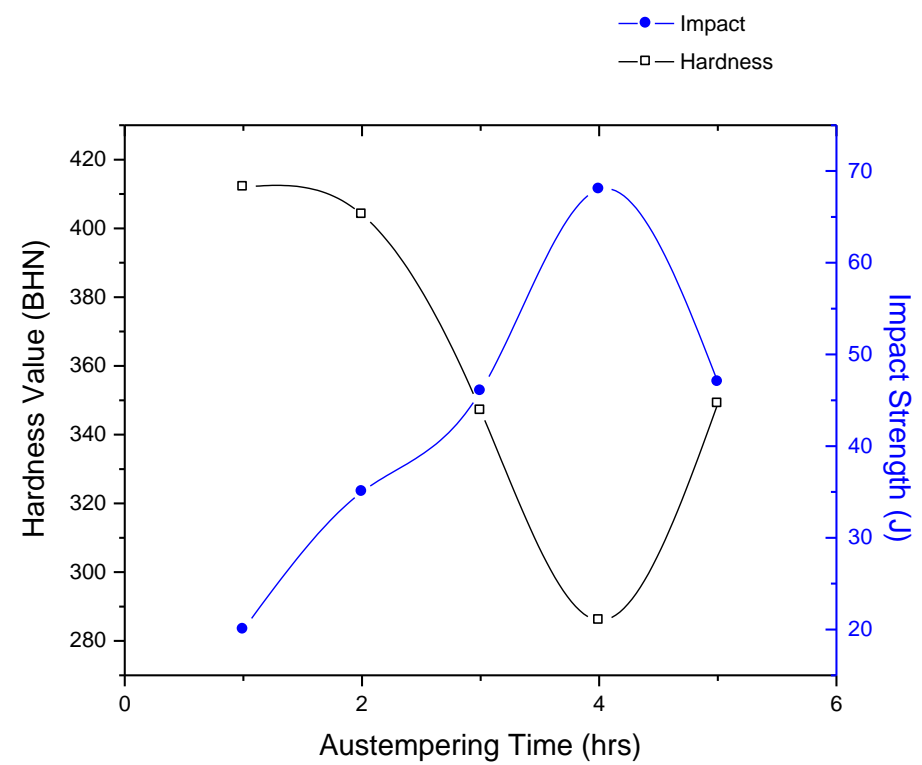

Fig. 3: Effect of Austempering Time on Hardness Superimposed on Impact Strength Values of Ductile Cast Iron Austenitized At $950^{\circ} \mathrm{C}$ and Austempered in Hot Jatropha Oil at $250^{\circ} \mathrm{C}$ for Varying Periods. 


\section{Conclusion}

This research work investigated the potential of Jatropha, seed oils as austempering quenchants for ductile cast iron. From the observations and analysis of the results obtained, it can be deduced that; Jatropha was able to cause the formation of 'ausferrite' structure at $250^{\circ} \mathrm{C}$ in the ductile cast iron. There is appreciable improvement in mechanical properties of ductile cast iron when austempered in jatropha seed oil. The as-cast tensile, hardness and impact enregy values of $570 \mathrm{~N} / \mathrm{mm}^{2} ; 196 \mathrm{BHN}$ and $31 \mathrm{~J}$ increased to $962 \mathrm{~N} / \mathrm{mm}^{2} ; 349 \mathrm{BHN}$ and $47 \mathrm{~J}$.

\section{References}

[1] T.N. Rouns, and K.B. Rundman, "Constitution of Austempered Ductile Iron and Kinetics ofAustempering", AFS Transactions, V. 95 , pp. 851 $-874.1987$.

[2] U. Batra, S. Ray, S.R. Prabhakar, The influence of Nickel and Copper on the Austempering of Ductile iron. Journal of materials Engineering and Performance. Volume 13(1) Feb., PP. 64-68 2004.

[3] J. R Keough, "The Development, Processing and Application of Austempered Ductile Iron"; Proceedings of 1991 World Conference on ADI, Bloomingdale, IL, March, Pp. 12-14, 1991.

[4] R. Prasad Putatunda, and Susil KInvestigations on the fracture toughness of austempered ductile irons austenitized at different temperatures, Materials Science and Engineering. A349 PP.136 - 149, 2003.

[5] S. Seshan, "Austempered Ductile Iron - The under exploited wonder cast iron" Indian foundry journal October, PP. 84 - 92, 1998.

[6] K.L. Hayrynen, ADI Another avenue for ductile iron foundries, Modern Casting, 8 PP.35-38,1995

[7] Olivera Eri, An austempering study of ductile iron alloyed with copper. J. Serb Chem. Soc. 70 (7) PP.1015-1022. 2005.

[8] G. E. Totten, H.M. Tensi and K. Lanier. "Performance of vegetable oils as a cooling medium in comparison to a standard mineral oil".Mat. Eng. and Perf, Vol. 8, No, 4, p. 409-416, 999.

[9] Ester Carvalho de Souza, and George E. Totten, "Quenchants Derived from Vegetable Oils as Alternatives to Petroleum Oil" Department of Materials, Aeronautical and Automobile Engineering, School of Engineering, São Carlos, SP, Brazil 2011. 